Check for updates

Cite this: Chem. Sci., 2019, 10, 2228

๑ All publication charges for this article have been paid for by the Royal Society of Chemistry

Received 20th October 2018 Accepted 18th December 2018

DOI: $10.1039 / \mathrm{c} 8 \mathrm{sc} 04681 \mathrm{f}$

rsc.li/chemical-science

\section{Benzene construction via Pd-catalyzed cyclization of 2,7-alkadiynylic carbonates in the presence of alkynes $\uparrow$}

\author{
Yuchen Zhang, (D) Wangteng Wu, Chunling Fu, Xin Huang* and Shengming Ma (D)*
}

A palladium-catalyzed highly regio- and chemo-selective cyclization of 2,7-alkadiynylic carbonates with functionalized alkynes to construct 1,3-dihydroisobenzofuran and isoindoline derivatives under mild conditions has been developed. Functional groups such as alcohol, sulfonamide, and indoles could be well tolerated. After careful mechanistic studies, a mechanism involving oxidative addition and regioselectivity-defined double alkyne insertions has been proposed.

\section{Introduction}

Benzocyclopentane derivatives, especially those containing oxygen and nitrogen heterocycles, exist widely in natural products and biologically active molecules: ${ }^{1}$ the phthalan (1,3dihydroisobenzofuran) and isoindoline skeletons are representative examples (Fig. 1), ${ }^{2}$ which are also important building blocks in organic synthesis. ${ }^{3}$ Common approaches for the construction of phthalan and isoindoline structures include: (1) $[2+2+2]$ cycloaddition reactions of 1,6-diynes with alkynes; ${ }^{4-11}$ (2) tetradehydro-Diels-Alder reaction of eneynes and alkynes or hexadehydro-Diels-Alder reaction of 1,3,8triynes and electrophiles; $;^{12}$ (3) domino reaction consisting of Heck couplings and consecutive $6 \pi$-electrocyclizations or

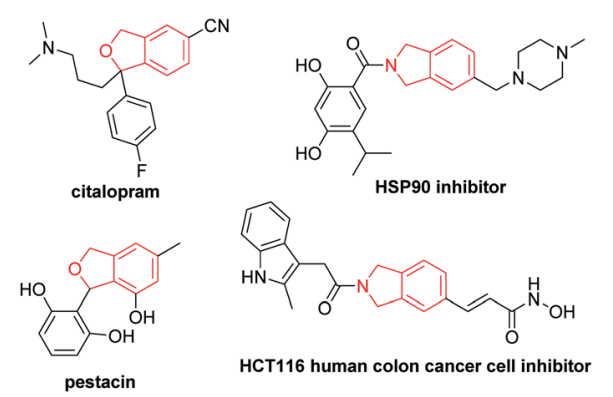

Fig. 1 Some typical natural or bioactive phthalans and isoindolines compounds.

\footnotetext{
Laboratory of Molecular Recognition and Synthesis, Department of Chemistry, Zhejiang University, Hangzhou 310027, Zhejiang, People's Republic of China. E-mail: xinhuangzju@zju.edu.cn; masm@sioc.ac.cn

$\dagger$ Electronic supplementary information (ESI) available: Experimental section, characterization of all the compounds, and copies of ${ }^{1} \mathrm{H}$ NMR and ${ }^{13} \mathrm{C}$ NMR spectra. CCDC 1849157, 1849158 and 1855724. For ESI and crystallographic data in CIF or other electronic format see DOI: $10.1039 / \mathrm{c} 8 \mathrm{sc} 04681 \mathrm{f}$
}

Sonogashira couplings and sequenced Garratt-Braverman cyclization of alkenyl halides and 1,6-diynes. ${ }^{13}$

Among all these methods, transition metal-catalyzed $[2+2+$ 2] cyclization of 1,6-diynes and alkynes is the most straightforward one. ${ }^{4-11}$ However, there is an issue of regioselectivity when non-symmetric 1,6-diynes and non-symmetric alkynes were applied (Scheme 1, eqn (1)). ${ }^{4-11}$ Based on our previous explorations in the tandem reactions between 2,7-alkadiynyl carbonates 3 and various allenes to construct fused tricycles, ${ }^{14}$ we envisioned a new approach to benzocyclopentanes by applying Pd-catalyzed tandem reaction of 2,7-alkadiynyl carbonates 3 with functionalized terminal or non-terminal alkynes $\mathbf{4}$, in which the selectivity issue may be addressed by starting the cyclization from the oxidative addition of the propargylic carbonate unit to afford allenylpalladium intermediate $\mathbf{A}$. Then the defined exo-insertion of the intramolecular alkyne and the

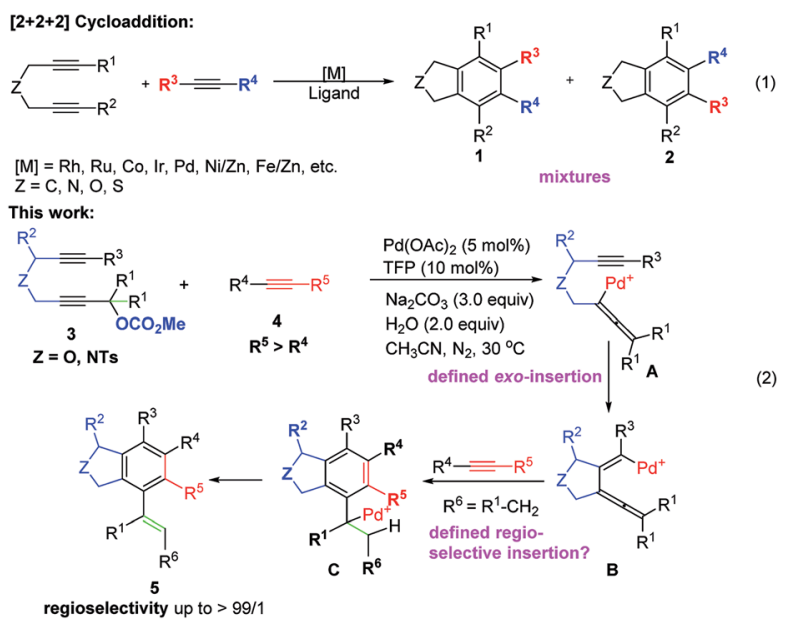

Scheme 1 The transition metal-catalyzed $[2+2+2]$ cyclotrimerization and cyclization of 2,7-alkadiynyl carbonate 3 in the presence of functionalized alkynes 4 . 
subsequent regio-selective insertion of the intermolecular alkyne would produce benzylpalladium intermediate $\mathbf{C}$, which underwent $\beta-\mathrm{H}$ elimination to give the final alkenyl benzene product (Scheme 1, eqn (2)). Here we wish to report the realization of such a concept.

\section{Results and discussion}

Initially we conducted the reaction of 2,7-alkadiynylic carbonate $3 a \quad(0.3 \mathrm{mmol})$ and 4-methyl- $N$-(prop-2-yn-1-yl)benzenesulfonamide $4 a$ (1.2 equiv.) under the catalysis of $\mathrm{Pd}(\mathrm{OAc})_{2}$ ( $5 \mathrm{~mol} \%$ ) and TFP $(10 \mathrm{~mol} \%)$ in the presence of $\mathrm{K}_{2} \mathrm{CO}_{3}(3.0$ equiv.) and $\mathrm{H}_{2} \mathrm{O}$ (2.0 equiv.) at $70{ }^{\circ} \mathrm{C}$ in $\mathrm{CH}_{3} \mathrm{CN}$. Interestingly, a pair of regioisomers $5 \mathbf{a a}$ and $6 \mathbf{a a}$ were observed in $81 \%$ and $3 \%$ yields, respectively, demonstrating a high regioselectivity. In addition, $2 \%$ yield of the cyclization product 7 aa was obtained (entry 1, Table 1). Encouraged by this exciting observation, the influence of the critical reaction parameters was investigated. Firstly, considering of our previous works, ${ }^{14 b, 15}$ an appropriate amount of water may increase the solubility of $\mathrm{K}_{2} \mathrm{CO}_{3}$ in $\mathrm{CH}_{3} \mathrm{CN}$, the effect of water was tested: the reaction failed to give better results when more water or no water were added (entries 2 and 3, Table 1). After screening a series of mono-phosphine ligand such as $\mathrm{PPh}_{3}, \mathrm{LB}-\mathrm{Phos} \cdot \mathrm{HBF}_{4}{ }^{16}$ and Gorlos-Phos $\cdot \mathrm{HBF}_{4},{ }^{17}$ it was found that TFP was still the best (entries 4-6, Table 1). The effect of base was also investigated: the reactions using $\mathrm{NaOH}$ or $\mathrm{NEt}_{3}$ as the base produced 5aa in lower yields with a poorer selectivity (entries 7 and 8 , Table 1). $\mathrm{Na}_{2} \mathrm{CO}_{3}$ was slightly better than $\mathrm{K}_{2} \mathrm{CO}_{3}$, resulting in $82 \%$ yield of 5 aa (entry 9 , Table 1 ).

Further solvent screening showed that the reactions in dioxane, DMSO, DMF, or DCE all delivered poorer results than those in $\mathrm{CH}_{3} \mathrm{CN}$ (entries 1-4, Table 2). It is worth mentioning that the efficiency, yield, and selectivity could be kept at the same level when the reaction was conducted at a lower temperature of $30^{\circ} \mathrm{C}$ (entries 5-7, Table 2). The reaction at $10^{\circ} \mathrm{C}$ is sluggish (entry 8 , Table 2). Based on these studies, the optimal mild conditions have been defined as follows: $\mathrm{Pd}(\mathrm{OAc})_{2}(5 \mathrm{~mol} \%)$, TFP $(10 \mathrm{~mol} \%)$, $\mathrm{Na}_{2} \mathrm{CO}_{3}$ (3.0 equiv.), and $\mathrm{H}_{2} \mathrm{O}$ (2.0 equiv.) in $\mathrm{CH}_{3} \mathrm{CN}$ at $30{ }^{\circ} \mathrm{C}$.

The scope of the terminal alkynes was examined by using methyl (2-methyl-5-((3-phenylprop-2-yn-1-yl)oxy)pent-3-yn-2-yl) carbonate (3a) as the model substrate on a $1 \mathrm{mmol}$ scale (Table 3). The reaction of $\mathbf{3 a}$ with propargyl tosylamide $\mathbf{4 a}$ afforded 5aa/6aa in $78 \%$ yield with a selectivity of $97 / 3$. When propargyl alcohol $\mathbf{4 b}$ was used, 5ab/6ab was obtained in $72 \%$ yield with the same selectivity. In light of the fact that the indole skeletons are very common in natural products and biologically active molecules, ${ }^{\mathbf{1 8}}$ it is interesting to note that the reactions with a series of $N$-propargyl indole derivatives (4c-4f) also worked, affording the phthalan derivatives bearing an indole ring 5ac/6ac-5af/6af in 66-69\% yields with a ratio of 95/5 > 99/ 1. Synthetically useful groups such as methyl, formyl, bromo could be introduced at different positions in the indole ring. The structure of product was unambiguously established by the $\mathrm{X}$-ray single crystal diffraction analysis of 5ae (Fig. 2). ${ }^{19}$

Next, the reactivity of various oxygen- or nitrogen-tethered 2,7-alkadiynylic carbonates was examined with different functionalized terminal alkynes (Table 4). In addition to being methyl groups, the two $\mathrm{R}^{1}$ groups could be a five- or sixmembered ring. The corresponding products $5 \mathbf{b a} / \mathbf{6 b a}$ and $5 \mathbf{j a} /$ 6ja were isolated in $79 \%$ yield with a selectivity of $98 / 2$ and $53 \%$ yield with a selectivity of 90/10, respectively. The substrates with the Ar group bearing either electron-rich or electron-deficient

Table 1 The effect of water, ligand, and base ${ }^{a}$

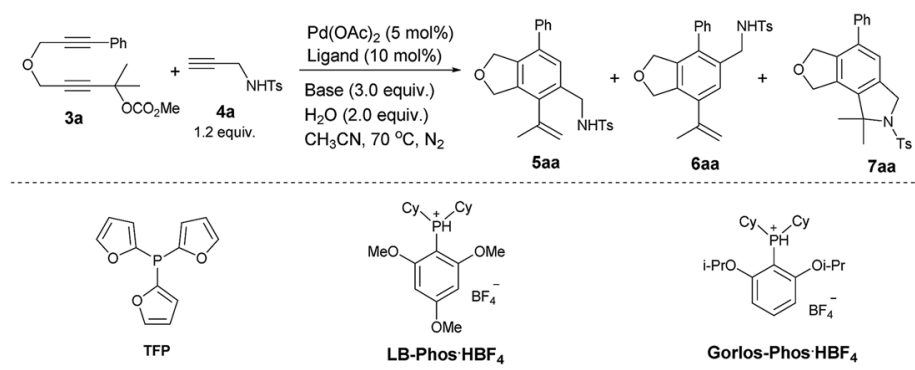

\begin{tabular}{|c|c|c|c|c|c|}
\hline Entry & Ligand & Base & Time (h) & Yield of $5 \mathbf{a a} / 6 \mathbf{a a} / 7 \mathbf{a a}^{b}(\%)$ & Recovery of $3 \mathbf{a}^{b}(\%)$ \\
\hline 1 & TFP & $\mathrm{K}_{2} \mathrm{CO}_{3}$ & 2 & $81 / 3 / 2$ & 0 \\
\hline $2^{c}$ & TFP & $\mathrm{K}_{2} \mathrm{CO}_{3}$ & 2 & $76 / 3 / 3$ & 0 \\
\hline 4 & $\mathrm{PPh}_{3}$ & $\mathrm{~K}_{2} \mathrm{CO}_{3}$ & 26 & $37 / 5 / 5$ & 14 \\
\hline 5 & LB-Phos $\cdot \mathrm{HBF}_{4}$ & $\mathrm{~K}_{2} \mathrm{CO}_{3}$ & 24 & $19 / 3 / 2$ & 43 \\
\hline 6 & Gorlos-Phos $\cdot \mathrm{HBF}_{4}$ & $\mathrm{~K}_{2} \mathrm{CO}_{3}$ & 24 & $31 / 4 / 2$ & 27 \\
\hline 9 & TFP & $\mathrm{Na}_{2} \mathrm{CO}_{3}$ & 2 & $82 / 3 / 2$ & $\mathbf{0}$ \\
\hline
\end{tabular}

${ }^{a}$ Reaction condition: $3 \mathbf{a}(0.3 \mathrm{mmol})$, $4 \mathrm{a}$ (1.2 equiv.), $\mathrm{Pd}(\mathrm{OAc})_{2}(5 \mathrm{~mol} \%)$, ligand $(10 \mathrm{~mol} \%)$, base (3.0 equiv.), and $\mathrm{H}_{2} \mathrm{O}\left(2.0\right.$ equiv.) in $\mathrm{CH}_{3} \mathrm{CN}(3.0 \mathrm{~mL})$ at $70{ }^{\circ} \mathrm{C}$ unless otherwise noted. ${ }^{b}$ Determined by the ${ }^{1} \mathrm{H}$ NMR analysis of the crude product using mesitylene as the internal standard. ${ }^{c} \mathrm{H}_{2} \mathrm{O}(4.0$ equiv.) were added. ${ }^{d}$ No $\mathrm{H}_{2} \mathrm{O}$ was added. 
Table 2 The effect of solvent and temperature ${ }^{a}$

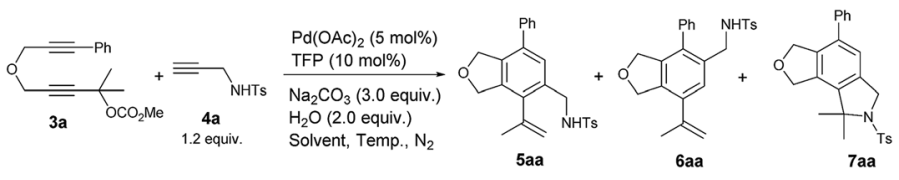

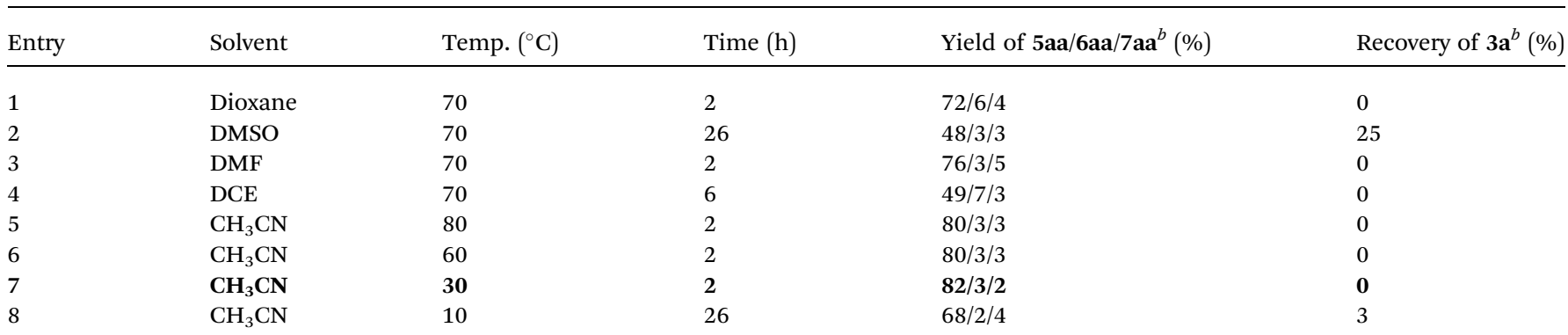

${ }^{a}$ Reaction condition: $3 a(0.3 \mathrm{mmol}), \mathbf{4 a}\left(1.2\right.$ equiv.), $\mathrm{Pd}(\mathrm{OAc})_{2}(5 \mathrm{~mol} \%)$, TFP $(10 \mathrm{~mol} \%), \mathrm{Na}_{2} \mathrm{CO}_{3}\left(3.0\right.$ equiv.), and $\mathrm{H}_{2} \mathrm{O}(2.0$ equiv.) in solvent (3.0 mL).

${ }^{b}$ Determined by the ${ }^{1} \mathrm{H}$ NMR analysis of the crude product using mesitylene as the internal standard.

Table 3 Scope of terminal alkynes $4 .^{a, b, c}$

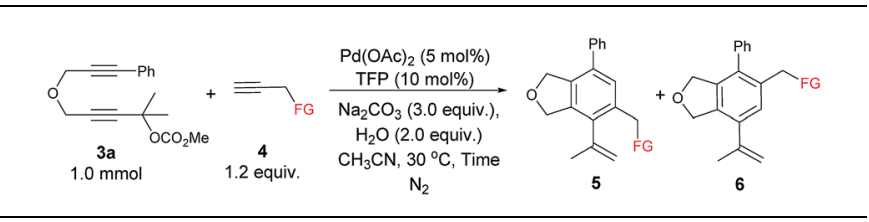

5aa/6aa: $78 \%, 97: 3,3 \mathrm{~h}$

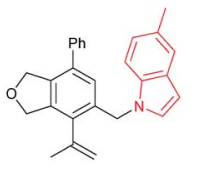

5ad/6ad: $66 \%, 95: 5,4.5 \mathrm{~h}$

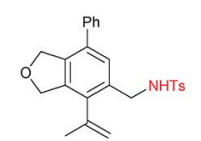

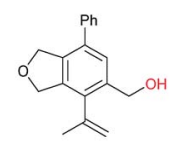

5ab/6ab: $72 \%, 97: 3,32 \mathrm{~h}$

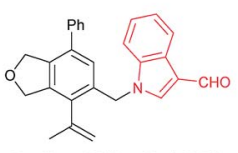

5ae/6ae: $68 \%,>99: 1,3.5 \mathrm{~h}$

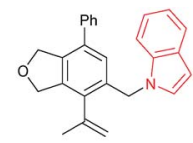

5ac/6ac: $69 \%, 95: 5,4 \mathrm{~h}$

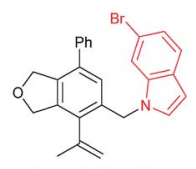

5af/6af: $68 \%,>99: 1,3.8 \mathrm{~h}$
${ }^{a}$ Reaction conditions: $3 a$ ( $\left.1.0 \mathrm{mmol}\right), \mathbf{4}$ (1.2 equiv.), $\mathrm{Pd}(\mathrm{OAc})_{2}(5 \mathrm{~mol} \%)$, TFP (10 mol\%), $\mathrm{Na}_{2} \mathrm{CO}_{3}$ (3.0 equiv.), and $\mathrm{H}_{2} \mathrm{O}$ (2.0 equiv.) in $\mathrm{CH}_{3} \mathrm{CN}$ (10 $\mathrm{mL})$ at $30{ }^{\circ} \mathrm{C} .{ }^{b}$ Combined isolated yield of 5 and $6 .{ }^{c}$ The ratio of 5 and 6 was determined by ${ }^{1} \mathrm{H}$ NMR analysis of the isolated product.

groups at the 8-position could also be applied, producing the expected products $\mathbf{5} \mathbf{c b} / \mathbf{6} \mathbf{c b}-\mathbf{5 f g} / \mathbf{6 f g}$ in $\mathbf{5 9 \%}-\mathbf{8 5 \%}$ yields with the ratio of $93 / 7-97 / 3$. This method could be extended to $8-\left(3^{\prime}-\right.$ thienyl), 8- ${ }^{n} \mathrm{Bu}, 8$-TMS and 6-propyl substituted 2,7-alkadiynylic

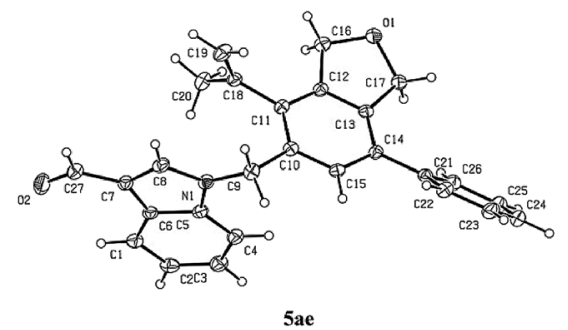

Fig. 2 ORTEP representation of 5 ae.
Table 4 The reaction of 2,7-alkadiynylic carbonates 3 with functionalized terminal alkynes $4^{a, b, c}$

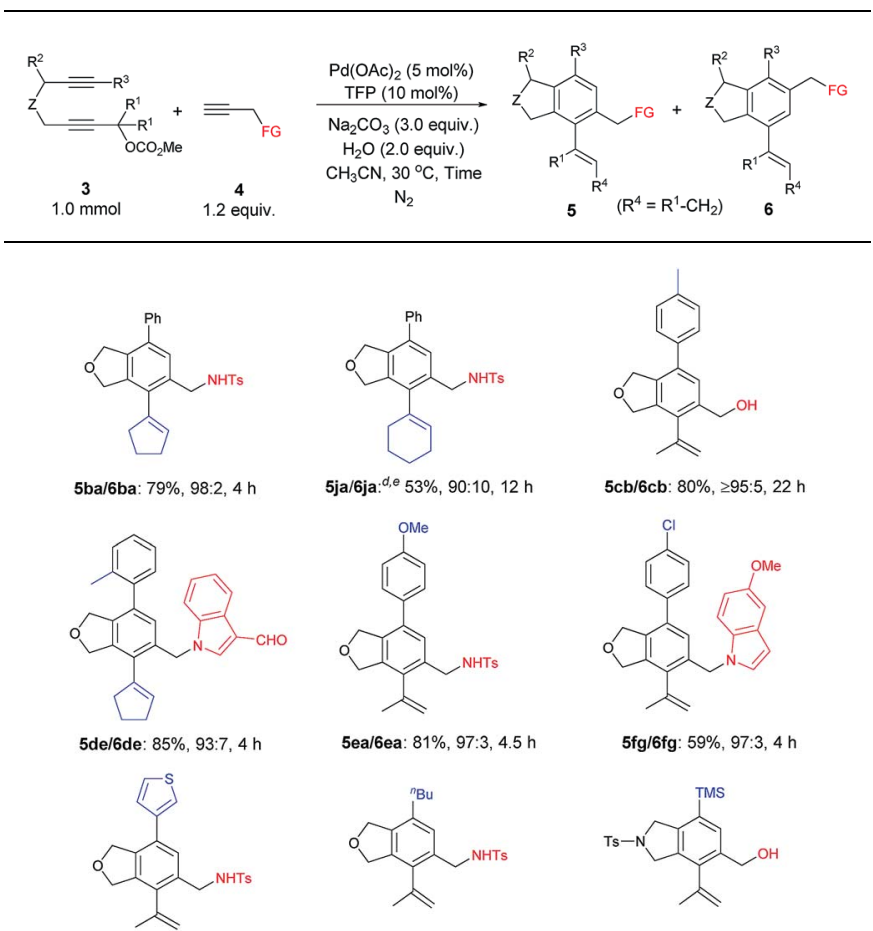

5ga/6ga: $66 \%, 96: 4,3.5 \mathrm{~h}$

5ka/6ka: 60\%, 96:4, $13 \mathrm{~h}$

$5|\mathbf{b} / 6| \mathbf{b} \cdot:^{e} 52 \%,>99: 1,13 \mathrm{~h}$
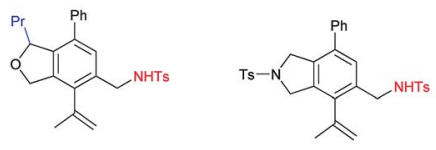

5ha/6ha: $82 \%,>99: 1,4.2 \mathrm{~h}$

5ia/6ia: $67 \%, 98: 2,4 \mathrm{~h}$

${ }^{a}$ Reaction conditions: 3 (1.0 mmol), 4 (1.2 equiv.), $\mathrm{Pd}(\mathrm{OAc})_{2}(5 \mathrm{~mol} \%)$, TFP (10 mol\%), $\mathrm{Na}_{2} \mathrm{CO}_{3}$ (3.0 equiv.), $\mathrm{H}_{2} \mathrm{O}$ (2.0 equiv.) in $\mathrm{CH}_{3} \mathrm{CN}$ (10 $\mathrm{mL}$ ) at $30{ }^{\circ} \mathrm{C} .{ }^{b}$ Combined yield of $\mathbf{5}$ and $\mathbf{6} .{ }^{c}$ The ratio of $\mathbf{5}$ and $\mathbf{6}$ was determined by ${ }^{1} \mathrm{H}$ NMR analysis of the isolated product. ${ }^{d}$ The reaction was conducted at $50{ }^{\circ} \mathrm{C}$ and $11 \%$ of $3 \mathbf{j}$ was recovered. ${ }^{e} 0.5 \mathrm{mmol}$ scale. 
carbonates to afford 5ga/6ga-5ha/6ha in moderate to good yields with the selectivity of $96 / 4$ to $>99 / 1$. Nitrogen-tethered 2,7-alkadiynylic carbonate $\mathbf{3} \mathbf{i}$ also worked and the isoindoline derivatives 5ia/6ia were obtained in $67 \%$ yield with a selectivity of $98 / 2$.

The reaction of $3 \mathbf{a}$ with $\mathbf{4 a}$ could be easily conducted on a gram-scale synthesis, resulting in the isolation of $1.42 \mathrm{~g}(85 \%)$ of 5aa/6aa with a selectivity of $97 / 3$ together with a $1 \%$ yield of 7 aa (eqn (3)).

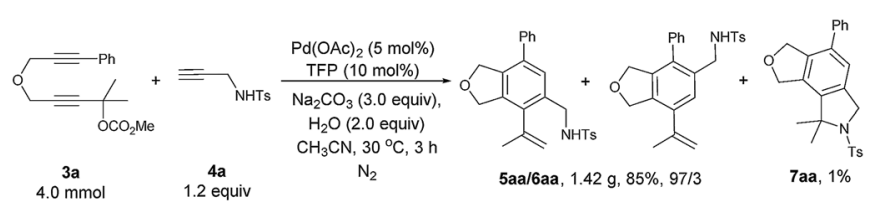

(3)

Some control experiments were conducted to obtain further information concerning the regioselectivity (Scheme 2). When phenyl or $n$-butyl substituted terminal alkyne $\mathbf{4 h}$ or $4 \mathbf{i}$ was used, the corresponding bicyclic product could still be formed with a decent regioselectivity, albeit in a much lower yield (Scheme 2a). Furthermore, the reaction of 3a with internal propargylic alcohol $4 \mathbf{j}$ could give $22 \%$ yield of the product 5 aj exclusively (Scheme 2b). X-ray single crystal diffraction analysis of 5aj showed that the regioselectivity was reversed-the $\mathrm{CH}_{2} \mathrm{OH}$ group was at the ortho-position of the phenyl group from 3a (Fig. 3). ${ }^{20}$ The reaction of $3 \mathbf{a}$ with 1-phenylpropyne $4 \mathbf{k}$ also gave $5 \mathbf{a k} / \mathbf{6 a k}$ in $11 \%$ yield with the same regioselectivity as $\mathbf{4 j}$, indicating that the hydroxy group should have nothing to do with the regioselectivity (Scheme 2b). The structure of 5ak was also confirmed by X-ray single crystal diffraction analysis (Fig. 3). ${ }^{21}$ However, the reaction did not work with 1,2-diphenylethyne 41 (Scheme $2 b)$. Thus, the regioselectivity obviously depends on the size of two groups of the alkyne: the larger group of the alkyne was more likely to stay away from the phenyl group originating from 3a. The failure of the reaction of $\mathbf{3 a - O H}$ with $\mathbf{4 a}$ under the standard conditions indicated that the reaction may not proceed the $[2+2+2]$ cycloaddition of the diyne unit in 3a with the $\mathrm{C}-\mathrm{C}$ triple bond in $\mathbf{4 a}$ (Scheme $2 \mathrm{c}$ ).
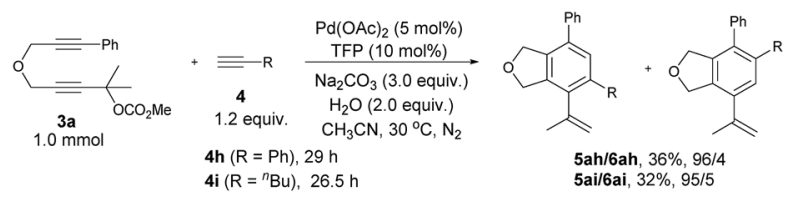

(a)

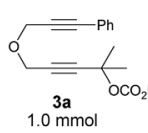

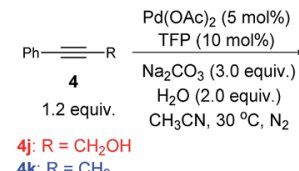

$$
\begin{aligned}
& \text { 4k: } \mathrm{R}=\mathrm{CH}_{3}
\end{aligned}
$$
5ai/6ai, 32\%, 95/5

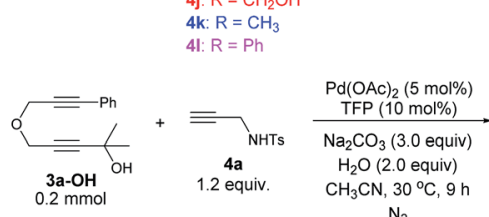

$\mathrm{N}_{2}$

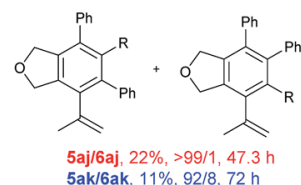

5ak/6ak, $11 \%, 92 / 8,72 \mathrm{~h}$

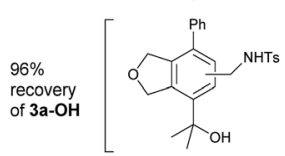

not observed
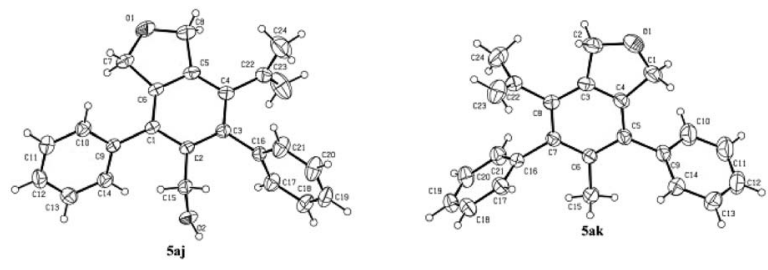

Fig. 3 ORTEP representations of 5aj and 5ak.

Based on these experimental results, a possible mechanism is shown in Scheme 3 by taking the reaction of $3 \mathbf{a}$ and $\mathbf{4 a}$ as an example: oxidative addition of $\mathbf{3 a}$ with the catalytically active species $\operatorname{Pd}(0)$ would give the allenylpalladium intermediate IN$\mathbf{1},{ }^{22}$ which undergoes intramolecular exo-mode insertion of the C-C triple bond to generate the alkenylpalladium species IN2 . $^{23}$ The species IN-2 would undergo intermolecular carbopalladation of the $\mathrm{C} \equiv \mathrm{C}$ bond of 4 a to generate a new alkenylpalladium intermediate IN-3 (path a) or IN-5 (path b). Then intramolecular carbopalladation of allene would form a new benzylpalladium intermediate IN-4 or IN-6. In the presence of a base, the key intermediate IN-4 could undergo the intramolecular nucleophilic attack or $\beta-\mathrm{H}$ elimination forming tricyclic product 7aa or the phthalan derivative 5aa and regenerating the catalytically active $\operatorname{Pd}(0)$. As a comparison, the key intermediate IN-6 could only go through the $\beta-\mathrm{H}$ elimination to deliver the phthalan derivative isomer 6aa. Obviously, there is a strong steric interaction between the phenyl group and $-\mathrm{CH}_{2} \mathrm{NHTs}$ moiety in $\mathbf{I N - 5}$, which make the reaction more likely to go through path a.

An alternative mechanism involving a Sonogashira coupling (path c) of $\mathbf{I N - 2}$ has been presented in Scheme 4. The resulted intermediate $\mathbf{I N - 8}$ could go through the Garratt-Braverman cyclization to deliver 5 aa. ${ }^{24}$

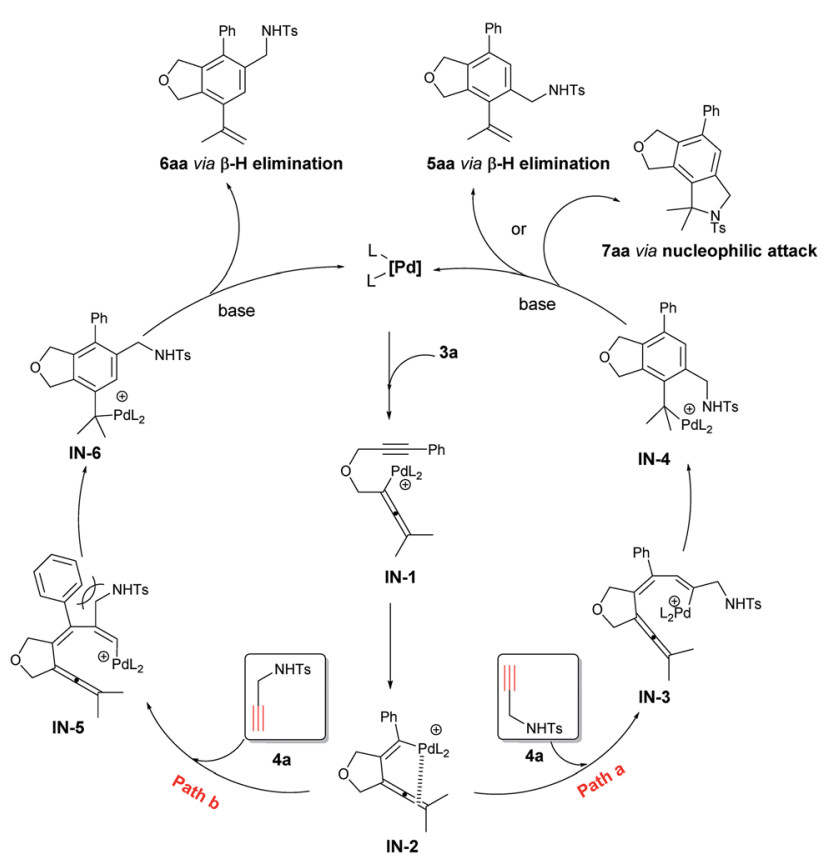

Scheme 3 The proposed mechanistic pathways.

Scheme 2 Control experiments. 

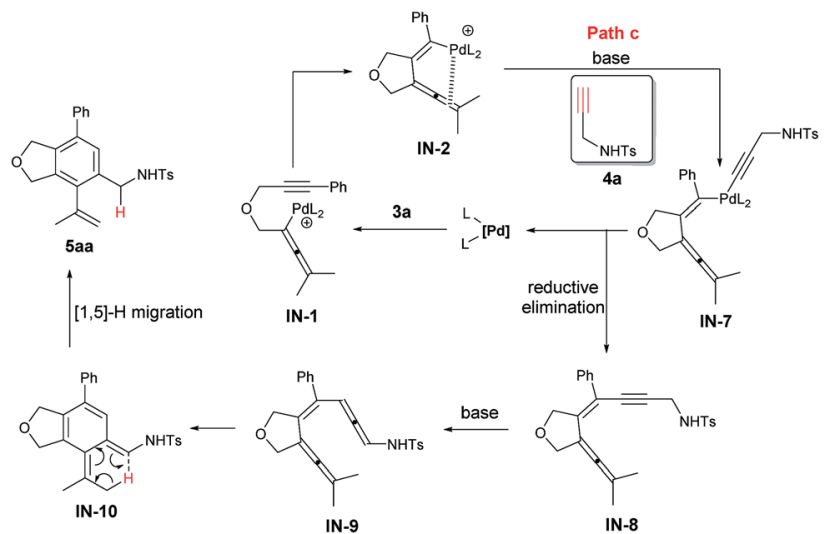

Scheme 4 An alternative mechanism involving a Sonogashira coupling of IN-2.

There should be a possibility of $[1,5]-\mathrm{H}$ migration process in path c. Thus, the reaction of $\mathbf{3 a - \mathbf { d } _ { \mathbf { 6 } }}$ and $\mathbf{4 a}$ was conducted and a mixture of $5 \mathbf{a a}-\mathbf{d}_{5}$ and $\mathbf{6 a a - d _ { 5 }}$ with a ratio $98 / 2$ with no deuteration at the $\alpha$-position of the NHTs group was afforded in $85 \%$ yield (eqn (4)), indicating that there is no $\mathrm{H}$-migration process, thus, path $\mathrm{c}$ is not viable for the formation of $\mathbf{5 a a}$.

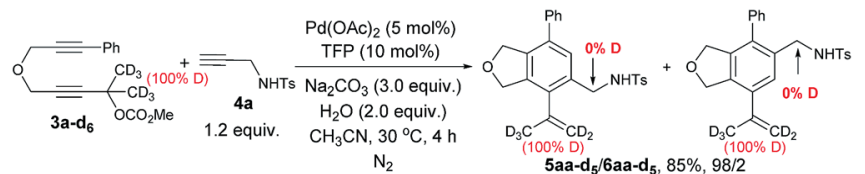

(4)

We also performed some deuterium labelling experiments for the investigation of the $\mathrm{D}-\mathrm{H}$ exchange of the terminal alkyne (Scheme 5). To our surprise, the reaction of 3a with $\mathbf{D}$ 4c under the standard conditions afforded 5ac/6ac in $84 \%$ yield with a selectivity of $95 / 5$ without any deuterium incorporation (eqn (5)). We conjectured that the deuterium atom may be easily exchanged with the hydrogen atom under the aqueous environment. Thus, $\mathrm{H}_{2} \mathrm{O}$ (2.0 equiv.) was replaced with $\mathrm{D}_{2} \mathrm{O}$ (2.0 equiv.), which led to the formation of 25\% deuterium incorporation in D-5ac (eqn (6)). Interestingly, the regioselectivity dropped from $95: 5$ to $81: 19$ (compare eqn (5) with eqn (6)), which might be explained by the steric effect of $\mathrm{D} v s . \mathrm{H}$ at $30{ }^{\circ} \mathrm{C}^{25}$ Of course, further attention is obviously needed. The $\mathrm{D}-\mathrm{H}$ exchange was also proven by the reaction of $\mathbf{D - 4 c}$ with $\mathrm{H}_{2} \mathrm{O}$ or the reaction of $4 \mathbf{c}$

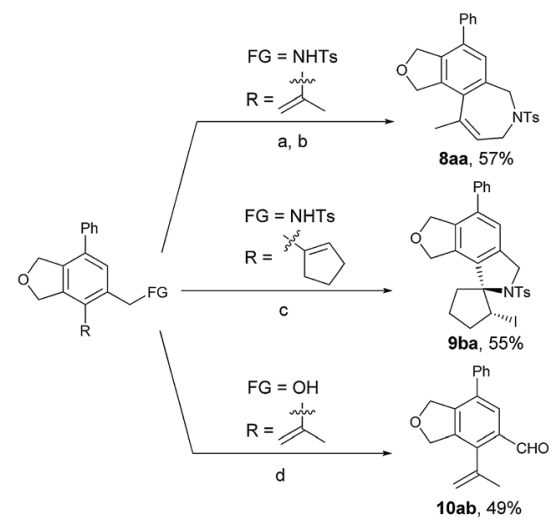

Scheme 6 Synthetic applications. Reaction condition: (a) allylbromide (2.0 equiv.), $\mathrm{K}_{2} \mathrm{CO}_{3}$ (4.0 equiv.), $\mathrm{CH}_{3} \mathrm{CN}$, refluxed $\left(85^{\circ} \mathrm{C}\right), 4 \mathrm{~h}$; (b) Grubbs' II catalyst (10 mol\%), toluene, $80{ }^{\circ} \mathrm{C}, 26 \mathrm{~h}$; (c) NIS (1.5 equiv.), $\mathrm{CH}_{3} \mathrm{CN} / \mathrm{H}_{2} \mathrm{O}=15 / 1, \mathrm{rt}, 27 \mathrm{~h}$. (d) $\mathrm{Fe}\left(\mathrm{NO}_{3}\right)_{3} \cdot 9 \mathrm{H}_{2} \mathrm{O}$ (10 mol\%), TEMPO (10 mol\%), $\mathrm{NaCl}(5 \mathrm{~mol} \%), \mathrm{CH}_{2} \mathrm{Cl}_{2}, \mathrm{rt}, 17.5 \mathrm{~h}$.

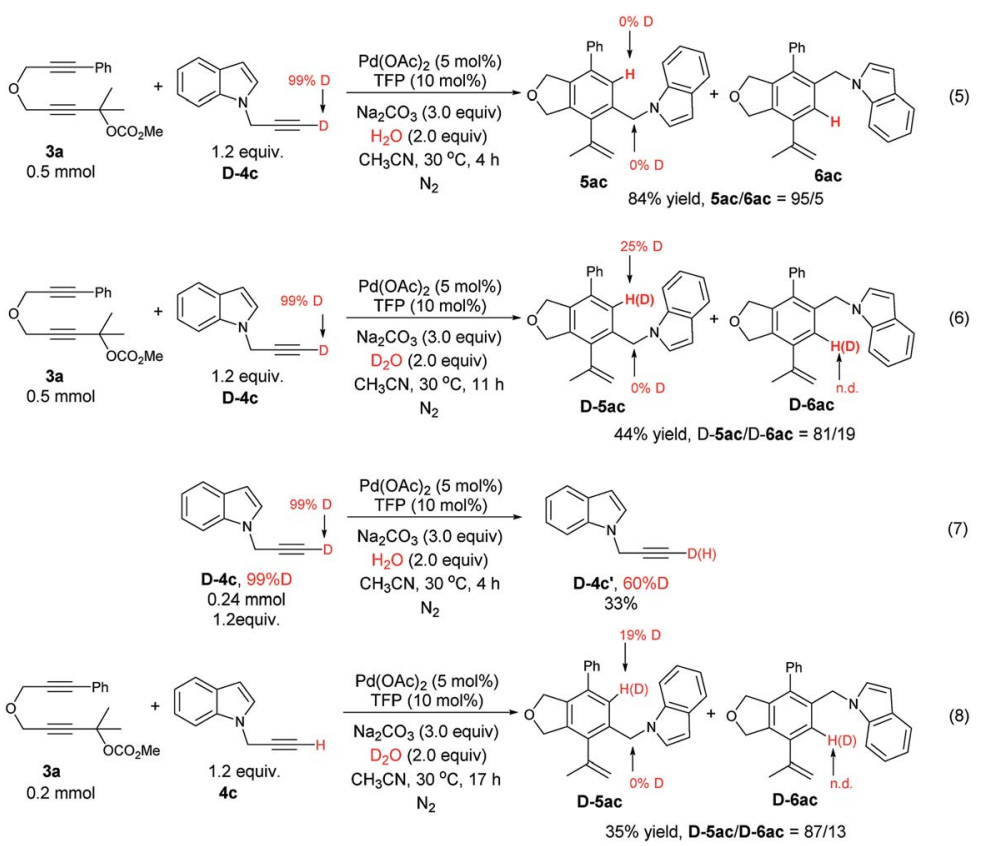

Scheme 5 Deuterium labeling experiments: investigating of the $\mathrm{D}-\mathrm{H}$ exchange of the terminal alkyne ( $\mathrm{n} . \mathrm{d}$. = not able to be determined by ${ }^{1} \mathrm{H}$ NMR analysis). 
with 3a in the presence of $\mathrm{D}_{2} \mathrm{O}$ (eqn (7) and (8)). These experimental facts further support the mechanism shown in Scheme 3.

In order to show the potential of the products, some synthetic applications have been conducted (Scheme 6). The bicyclic product 5aa could be transferred to tricyclic isobenzofuro[5,4-c]azepine derivative 8 aa in $57 \%$ yield after an allylation-RCM process. ${ }^{26}$ The tetracyclic product 9 ba containing a spirocycle skeleton can be easily obtained through an electrophilic cyclization with NIS (1.5 equiv.). ${ }^{27}$ The $\mathrm{Fe}\left(\mathrm{NO}_{3}\right)_{3}{ }^{-}$ $.9 \mathrm{H}_{2} \mathrm{O}$-TEMPO-NaCl-catalyzed oxidation of $5 \mathbf{a b}$ proceeded smoothly to give the aryl aldehyde $10 \mathrm{ab}$ in $49 \%$ yield. ${ }^{28}$

\section{Conclusions}

In summary, we have developed a highly regio- and chemoselective annulation of 2,7-alkadiynylic carbonates in the presence of functionalized alkynes to construct 1,3-dihydroisobenzofuran and isoindoline derivatives under mild conditions. Functional groups such as sulfonamide, alcohol, and indoles could be kept untouched, which provides a chance for many further transformations to more complicated polycycles. Further studies in this area are being pursued in our laboratory.

\section{Conflicts of interest}

There are no conflicts to declare.

\section{Acknowledgements}

Financial supports from the National Natural Science Foundation of China (21690063) and National Basic Research Program of China (2015CB856600) are greatly appreciated. We thank Mr Yangguangyan Zheng in this group for reproducing the preparation of $\mathbf{5 a e}, \mathbf{5} \mathbf{c b}$, and $\mathbf{5 d e}$. Shengming Ma is a Qiu Shi Adjunct Professor at Zhejiang University.

\section{Notes and references}

1 (a) S. O. Simonetti, E. L. Larghi, A. B. J. Bracca and T. S. Kaufman, Nat. Prod. Rep., 2013, 30, 941; (b) R. Karmakar, P. Pahari and D. Mal, Chem. Rev., 2014, 114, 6213; (c) W. Jiaang, Y. Chen, T. Hsu, S. Wu, C. Chien, C. Chang, S. Chang, S. Lee and X. Chen, Bioorg. Med. Chem. Lett., 2005, 15, 687; (d) S. Van Goethem, P. Van der Veken, V. Dubois, A. Soroka, A.-M. Lambeir, X. Chen, A. Haemers, S. Scharpé, I. De Meester and K. Augustyns, Bioorg. Med. Chem. Lett., 2008, 18, 4159; (e) E. Pinard, D. Alberati, M. Bender, E. Borroni, V. Brom, S. Burner, H. Fischer, D. Hainzl, R. Halm, N. Hauser, S. Jolidon, J. Lengyel, H. Marty, T. Meyer, J. Moreau, R. Mory, R. Narquizian, R. D. Norcross, P. Schmid, R. Wermuth and D. Zimmerli, Bioorg. Med. Chem. Lett., 2010, 20, 6960; $(f)$ S. Tso, M. Lou, C. Wu, W. Gui, J. L. Chuang, L. K. Morlock, N. S. Williams, R. M. Wynn, X. Qi and D. T. Chuang, J. Med. Chem., 2017, 60, 1142; $(g)$ T. Mancilla-Percino,
C. R. Trejo-Muñoz, J. A. Díaz-Gandarilla, P. TalamásRohana, J. E. Guzmán Ramírez, J. Cervantes and F. Ortíz, Arch. Pharm. Chem. Life Sci., 2016, 349, 175; (h) S. Tso, X. Qi, W. Gui, C. Wu, J. L. Chuang, I. Wernstedt-Asterholm, L. K. Morlock, K. R. Owens, P. E. Scherer, N. S. Williams, U. K. Tambar, R. M. Wynn and D. T. Chuang, J. Biol. Chem., 2014, 289, 4432.

2 (a) B. G. Pollock, Expert Opin. Pharmacother., 2001, 2, 681; (b) J. K. Harper, A. M. Arif, E. J. Ford, G. A. Strobel, J. A. Porco Jr, D. P. Tomer, K. L. Oneill, E. M. Heider and D. M. Grant, Tetrahedron, 2003, 59, 2471; (c) J. Ren, J. Li, Y. Wang, W. Chen, A. Shen, H. Liu, D. Chen, D. Cao, Y. Li, N. Zhang, Y. Xu, M. Geng, J. He, B. Xiong and J. Shen, Bioorg. Med. Chem. Lett., 2014, 24, 2525; (d) M. Shultz, J. Fan, C. Chen, Y. S. Cho, N. Davis, S. Bickford, K. Buteau, X. Cao, M. Holmqvist, M. Hsu, L. Jiang, G. Liu, Q. Lu, C. Patel, J. R. Suresh, M. Selvaraj, L. Urban, P. Wang, Y. Yan-Neale, L. Whitehead, H. Zhang, L. Zhou and P. Atadja, Bioorg. Med. Chem. Lett., 2011, 21, 4909.

3 (a) J. Almena, F. Foubelo and M. Yus, Tetrahedron, 1996, 52, 8545; (b) J. Almena, F. Foubelo and M. Yus, Tetrahedron, 1995, 51, 3351; (c) U. Azzena, S. Demartis, M. G. Fiori, G. Melloni and L. Pisano, Tetrahedron Lett., 1995, 36, 8123; (d) U. Azzena, S. Demartis and G. Melloni, J. Org. Chem., 1996, 61, 4913; (e) D. García, F. Foubelo and M. Yus, Tetrahedron, 2008, 64, 4275; $(f)$ D. Y. Li, X. S. Shang, G. R. Chen and P. N. Liu, Org. Lett., 2013, 15, 3848; $(g)$ H. X. Siyang, X. R. Wu, H. L. Liu, X. Y. Wu and P. N. Liu, J. Org. Chem., 2014, 79, 1505; (h) J. G. Sośnicki, Monatsh. Chem., 2000, 131, 475; ( $i$ ) T. Ohmura, A. Kijima and M. Suginome, Org. Lett., 2011, 13, 1238; (j) P. Galletti, F. Funiciello, R. Soldati and D. Giacomini, Adv. Synth. Catal., 2015, 357, 1840.

4 For selected reviews, see: (a) P. R. Chopade and J. Louie, $A d v$. Synth. Catal., 2006, 348, 2307; (b) K. Tanaka, Bull. Chem. Soc. Jpn., 2018, 91, 187; (c) S. Saito and Y. Yamamoto, Chem. Rev., 2000, 100, 2901; (d) J. A. Varela and C. Saá, Chem. Rev., 2003, 103, 3787; (e) B. Heller and M. Hapke, Chem. Soc. Rev., 2007, 36, 1085; $(f)$ G. Domínguez and J. Pérez-Castells, Chem. Soc. Rev., 2011, 40, 3430; (g) N. Weding and M. Hapke, Chem. Soc. Rev., 2011, 40, 4525; (h) S. Kotha, E. Brahmachary and K. Lahiri, Eur. J. Org. Chem., 2005, 4741; (i) S. Okamoto, Heterocycles, 2012, 85, 1579; (j) T. Shibata and K. Tsuchikama, Org. Biomol. Chem., 2008, 6, 1317; (k) M. Babazadeh, S. Soleimani-Amiri, E. Vessally, A. Hosseiniand and L. Edjlali, RSC Adv., 2017, 7, 43716; $(l)$ S. Okamoto and Y. Sugiyama, Synlett, 2013, 24, 1044; $(\mathrm{m})$ Y. Shibata and K. Tanaka, Synthesis, 2012, 44, 323; (n) Y. Yamamoto, Tetrahedron Lett., 2017, 58, 3787.

5 For selected reports on Fe-catalyzed cyclization reactions, see: (a) D. Brenna, M. Villa, T. N. Gieshoff, F. Fischer, M. Hapke and A. J. Wangelin, Angew. Chem., Int. Ed., 2017, 56, 8451; $(b)$ N. Saino, D. Kogure and S. Okamoto, Org. Lett., 2005, 7, 3065; (c) D. Bhatt, H. Chowdhury and A. Goswami, Org. Lett., 2017, 19, 3350; (d) N. Saino, D. Kogure, K. Kase and S. Okamoto, J. Organomet. Chem., 2006, 691, 3129. 
6 For selected reports on Ru-catalyzed cyclization reactions, see: (a) R. W. Foster, C. J. Tame, H. C. Hailes and T. D. Sheppard, Adv. Synth. Catal., 2013, 355, 2353; (b) Y. Yamamoto, R. Ogawa and K. Itoh, Chem. Commun., 2000, 549; (c) B. Witulski, T. Stengel and J. M. FernándezHernández, Chem. Commun., 2000, 1965; (d) E. Kang, C. Kang, S. Yang, E. Oks and T. Choi, Macromolecules, 2016, 49, 6240; (e) Y. Yamamoto, K. Kinpara, T. Saigoku, H. Nishiyama and K. Itoh, Org. Biomol. Chem., 2004, 2, 1287; (f) R. Karmakar, K. Wang, S. Y. Yun, P. Mamidipalli and D. Lee, Org. Biomol. Chem., 2016, 14, 4782; $(g)$ F. Ye, M. Haddad, V. Michelet and V. Ratovelomanana-Vidal, Org. Lett., 2016, 18, 5612.

7 For selected reports on Co-catalyzed cyclization reactions, see: (a) P. Jungk, F. Fischer and M. Hapke, ACS Catal., 2016, 6, 3025; (b) A. Geny, N. Agenet, L. Iannazzo, M. Malacria, C. Aubert and V. Gandon, Angew. Chem., Int. Ed., 2009, 48, 1810; (c) T. Sugihara, A. Wakabayashi, Y. Nagai, H. Takao, H. Imagawa and M. Nishizawa, Chem. Commun., 2002, 576; (d) M. Wu, M. Shanmugasundaram and C. Cheng, Chem. Commun., 2003, 718; (e) K. E. Ruhl and T. Rovis, J. Am. Chem. Soc., 2016, 138, 15527; (f) P. Jungk, F. Fischer, I. Thiel and M. Hapke, J. Org. Chem., 2015, 80, 9781.

8 For selected reports on Ir-catalyzed cyclization reactions, see: (a) A. Auvinet, M. Ez-Zoubir, S. Bompard, M. R. Vitale, J. A. Brown, V. Michelet and V. Ratovelomanana-Vidal, ChemCatChem, 2013, 5, 2389; (b) A. Auvinet, M. Ez-Zoubir, M. R. Vitale, J. A. Brown, V. Michelet and V. Ratovelomanana-Vidal, ChemSusChem, 2012, 5, 1888.

9 For selected reports on Rh-catalyzed cyclization reactions, see: (a) B. Witulski and T. Stengel, Angew. Chem., Int. Ed., 1999, 38, 2426; (b) F. Ye, M. Haddad, V. RatovelomananaVidal and V. Michelet, Catal. Commun., 2018, 107, 78; (c) Y. Tahara, S. Obinata, K. S. Kanyiva, T. Shibata, A. Mándi, T. Taniguchi and K. Monde, Eur. J. Org. Chem., 2016, 1405; (d) F. E. McDonald, H. Y. H. Zhu and C. R. Holmquist, J. Am. Chem. Soc., 1995, 117, 6605; (e) J. Clayden and W. J. Moran, Org. Biomol. Chem., 2007, 5, 1028; (f) R. Grigg, R. Scott and P. Stevenson, Tetrahedron Lett., 1982, 23, 2691.

10 For selected reports on Ni-catalyzed cyclization reactions, see: (a) Y. Sato, T. Nishimata and M. Mori, J. Org. Chem., 1994, 59, 6133; (b) S. Ikeda, H. Watanabe and Y. Sato, J. Org. Chem., 1998, 63, 7026; (c) P. Turek, P. Novák, R. Pohl, M. Hocek and M. Kotora, J. Org. Chem., 2006, 71, 8978; (d) A. Jeevanandam, R. P. Korivi, I. Huang and C. Cheng, Org. Lett., 2002, 4, 807.

11 For selected reports on Pd-catalyzed cyclization reactions, see: (a) Y. Yamamoto, A. Nagata, H. Nagata, Y. Ando, Y. Arikawa, K. Tatsumi and K. Itoh, Chem. - Eur. J., 2003, 9, 2469; (b) P. Zhou, M. Zheng, H. Jiang, X. Li and C. Qi, J. Org. Chem., 2011, 76, 4759; (c) E. Negishi, L. S. Harring, Z. Owczarczyk, M. M. Mohamud and M. Ay, Tetrahedron Lett., 1992, 33, 3253; (d) Y. Yamamoto, A. Nagata and K. Itoh, Tetrahedron Lett., 1999, 40, 5035.

12 (a) P. Wessig and G. Müller, Chem. Rev., 2008, 108, 2051; (b) T. R. Hoye, B. Baire, D. W. Niu, P. H. Willoughby and
B. P. Woods, Nature, 2012, 490, 208; (c) N. J. Kramer, T. T. Hoang and G. B. Dudley, Org. Lett., 2017, 19, 4636; (d) L. Lu, X.-Y. Liu, X.-Z. Shu, K. Yang, K.-G. Ji and Y.-M. Liang, J. Org. Chem., 2009, 74, 474; (e) B. MartínMatute, D. J. Cárdenas and A. M. Echavarren, Angew. Chem., Int. Ed., 2001, 40, 4754; (f) A. S. K. Hashmi, M. Wölfle, F. Ata, M. Hamzic, R. Salathé and W. Frey, Adv. Synth. Catal., 2006, 348, 2501; (g) D. Niu, T. Wang, B. P. Woods and T. R. Hoye, Org. Lett., 2014, 16, 254; $(h)$ J. Chen, V. Palani and T. R. Hoye, J. Am. Chem. Soc., 2016, 138, 4318; (i) A. S. K. Hashmi, T. M. Frost and J. W. Bats, J. Am. Chem. Soc., 2000, 122, 11553; (j) A. S. K. Hashmi, M. Ghanbari, M. Rudolph and F. Rominger, Chem. - Eur. J., 2012, 18, 8113; (k) A. S. K. Hashmi, J. P. Weyrauch, E. Kurpejović, T. M. Frost, B. Miehlich, W. Frey and J. W. Bats, Chem. - Eur. J., 2006, 12, 5806.

13 (a) For a selected review, see: A. D. Meijere, P. V. Zezschwitz and S. Bräse, Acc. Chem. Res., 2005, 38, 413For selected reports on domino reactions of alkenyl or aryl halides with two acetylenic fragments, see: $(b)$ R. Shen, X. Huang and L. Chen, Adv. Synth. Catal., 2008, 350, 2865; (c) S. Zhu, J. Cao, L. Wu and X. Huang, J. Org. Chem., 2012, 77, 10409; (d) S. Torii, H. Okumoto and A. Nishimura, Tetrahedron Lett., 1991, 32, 4167; (e) P. J. Parsons, M. Stefinovic, P. Willis and F. Meyer, Synlett, 1992, 864; $(f)$ S. S. Goh, G. Chaubet, B. Gockel, M. A. Cordonnier, H. Baars, A. W. Phillips and E. A. Anderson, Angew. Chem., Int. Ed., 2015, 54, 12618; $(g)$ M. Leibeling, D. Koester, M. Pawliczek, S. Schild and D. Werz, Nat. Chem. Biol., 2010, 6, 199For selected reports on domino reactions of alkenyl or aryl halides with two alkynes, see: $(h)$ H. Kinoshita, H. Takahashi and K. Miura, Org. Lett., 2013, 15, 2962; (i) S. Kawasaki, T. Satoh, M. Miura and M. Nomura, J. Org. Chem., 2003, 68, 6836.

14 (a) X. Lian and S. Ma, Angew. Chem., Int. Ed., 2008, 47, 8255; (b) X. Huang, W. Wu, S. Song, C. Fu and S. Ma, Adv. Synth. Catal., 2016, 358, 2791.

15 Q. Li, C. Fu and S. Ma, Angew. Chem., Int. Ed., 2012, 51, 11783.

16 B. Lü, C. Fu and S. Ma, Tetrahedron Lett., 2010, 51, 1284.

17 B. Lü, P. Li, C. Fu, L. Xue, Z. Lin and S. Ma, Adv. Synth. Catal., 2011, 353, 100.

18 (a) T. Fischer, A. Najjar, F. Totzke, C. Schächtele, W. Sippl, C. Ritter and A. Hilgeroth, J. Enzyme Inhib. Med. Chem., 2017, 33, 1; (b) W. M. Eldehna, D. H. EL-Naggar, A. R. Hamed, H. S. Ibrahim, H. A. Ghabbour and H. A. Abdel-Azizb, J. Enzyme Inhib. Med. Chem., 2018, 33, 309; (c) W. M. Eldehna, R. I. Al-Wabli, M. S. Almutairi, A. B. Keeton, G. A. Piazza, H. A. Abdel-Aziz and M. I. Attia, J. Enzyme Inhib. Med. Chem., 2018, 33, 867; (d) F. Wang, Y. Fang, T. Zhu, M. Zhang, A. Lin, Q. Gu and W. Zhu, Tetrahedron, 2008, 64, 7986.

19 Crystal data for compound 5ae: $\mathrm{C}_{27} \mathrm{H}_{23} \mathrm{NO}_{2}$; $\mathrm{MW}=393.46$; orthorhombic space group $P b c a$; final $\mathrm{R}$ indices [I $>2 \backslash \mathrm{S}(\mathrm{I})$ ], $\mathrm{R}_{1}=0.0717, \mathrm{wR}_{2}=0.1322, \mathrm{R}$ indices (all data) $\mathrm{R}_{1}=$ 0.0937, $\mathrm{wR}_{2}=0.1440 ; \mathrm{a}=37.682(4) \AA, \mathrm{b}=6.9971(4) \AA, \mathrm{c}=$

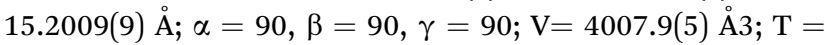


150.0 K; $\mathrm{Z}=8$; reflections collected/unique $23799 / 3672\left(\mathrm{R}_{\text {int }}\right.$ $=0.0793) ; \quad$ number of observations $\quad[>2 \backslash \mathrm{S}(\mathrm{I})]$ 2837, parameters: 272. CCDC 1849157 contains the supplementary crystallographic data for this paper. $\dagger$

20 Crystal data for compound 5aj: $\mathrm{C}_{24} \mathrm{H}_{22} \mathrm{O}_{2} ; \mathrm{MW}=342.41$; monoclinic space group $P 121 / n 1$; final $\mathrm{R}$ indices [I > $2 \backslash \mathrm{s}(\mathrm{I})], \mathrm{R}_{1}=0.0602, \mathrm{wR}_{2}=0.1251, \mathrm{R}$ indices (all data) $\mathrm{R}_{1}=$ 0.0921, $\mathrm{wR}_{2}=0.1457 ; \mathrm{a}=6.8864(5) \AA, \mathrm{b}=33.272(3) \AA$, $\mathrm{c}=$ 8.5011(8) $\AA$; $\alpha=90, \beta=104.932(8), \gamma=90 ; \mathrm{V}=1882.0(3)$ $\AA 3$; $\mathrm{T}=293.0 \mathrm{~K} ; \mathrm{Z}=4$; reflections collected/unique 7378 / $3441\left(\mathrm{R}_{\text {int }}=0.0345\right)$; number of observations $[>2 \backslash \mathrm{S}(\mathrm{I})] 2370$, parameters: 237. CCDC 1849158 contains the supplementary crystallographic data for this paper. $\dagger$

21 Crystal data for compound 5ak: $\mathrm{C}_{24} \mathrm{H}_{22} \mathrm{O}_{1} ; \mathrm{MW}=326.41$; triclinic space group $P-1$; final $\mathrm{R}$ indices $[\mathrm{I}>2 \backslash \mathrm{S}(\mathrm{I})], \mathrm{R}_{1}=$ $0.0624, \mathrm{wR}_{2}=0.1570, \mathrm{R}$ indices (all data) $\mathrm{R}_{1}=0.1055, \mathrm{wR}_{2}$ $=0.1984 ; \mathrm{a}=8.4646(7) \AA, \mathrm{b}=10.2366(11) \AA, \mathrm{c}=$ 11.8274(12) Аं; $\alpha=77.022(9), \beta=69.293(8), \gamma=74.924(8)$; $\mathrm{V}=915.61(16) \AA 30 ; \mathrm{T}=296.0 \mathrm{~K} ; \mathrm{Z}=2$; reflections collected/ unique $5997 / 3358\left(\mathrm{R}_{\text {int }}=0.0336\right)$; number of observations [>2\S(I)] 2007, parameters: 228. CCDC 1855724 contains the supplementary crystallographic data for this paper. $\dagger$
22 For slected reviews, see: (a) J. Tsuji and T. Mandai, Angew. Chem., Int. Ed. Engl., 1995, 34, 2589; (b) L. Guo, X. Duan and Y. Liang, Acc. Chem. Res., 2011, 44, 111; (c) J. Ye and S. Ma, Acc. Chem. Res., 2014, 47, 989.

23 (a) R. Grigg, R. Rasul and V. Savic, Tetrahedron Lett., 1997, 38, 1825; (b) F. Wang, X. Tong, J. Cheng and Z. Zhang, Chem. Eur. J., 2004, 10, 5338; (c) S. Song, C. Fu, X. Huang and S. Ma, Adv. Synth. Catal., 2018, 360, 1019.

24 J. Das, S. S. Bag and A. Basak, J. Org. Chem., 2016, 81, 4623. 25 J. D. Dunitz and R. M. Ibberson, Angew. Chem., Int. Ed., 2008, 47, 4208.

26 B. Bradshaw, P. Evans, J. Fletcher, A. T. L. Lee, P. G. Mwashimba, D. Oehlrich, E. J. Thomas, R. H. Davies, B. C. P. Allen, K. J. Broadley, A. Hamrounic and C. Escargueil, Org. Biomol. Chem., 2008, 6, 2138.

27 Y. Morino, I. Hidaka, Y. Oderaotoshi, M. Komatsu and S. Minakata, Tetrahedron, 2006, 62, 12247.

28 S. Ma, J. Liu, S. Li, B. Chen, J. Cheng, J. Kuang, Y. Liu, B. Wan, Y. Wang, J. Ye, Q. Yu, W. Yuan and S. Yu, Adv. Synth. Catal., 2011, 353, 1005. 